\title{
"A lost lady" eco-feminist interpretation
}

\author{
Jiahong JIE \\ Nanyang Medical College \\ Nanyang,473058 China
}

\begin{abstract}
Willa Cather • is One of the most important women writers of the United States in twentieth century, "A Lost Lady," marking her novel has reached a pinnacle of artistic realm, which analyses it from the ecological feminism, that the dual oppression of women and nature is the result of the ruling logic of the dual system, while understanding Kaiser's ecological thinking allows us to have a more clear understanding of the urgency and importance of maintaining the harmony between man and nature in today's deteriorative ecological crisis and the crisis of survival.
\end{abstract}

Keywords- Willa Cather •; "A Lost Lady"; ecofeminism

\section{INTRODUCTION}

Willa Cather is one of the most important and most prolific female writers in the late nineteenth century and early twentieth century of America. She strokes soulful and beautiful lyrical approach, from all sides to depict the indomitable entrepreneurial spirit and the indomitable fortitude character of Midwest Blazers in the late nineteenth century, to praise their noble sentiments and a beautiful soul, so she is famous for Jimmy • Geismar's critic as "the process of spiritual beauty of material defenders." In Willa Cather's life she complete more than 16 novels and short

Novels, several works embody in the harmony between man and nature scenes. Her novels have a wide theme, the most important one is the description of real life of the pioneers in the American Midwest frontier areas. "A Lost Lady," is one of the masterpieces of the late Catherine works in this category, published in 1923, it makes that the art of the novel waited by Catherine has reached a pinnacle of the realm. Like its heroine, the novel always "suggests something much more lovely than her own," it seems that in a "self

Contradictory charm "It is endless figured all along, critics from a broad perspective on her work made a variety of interpretation. Today, working for the Ecological Cather novel and eco feminist criticism is getting more and more attention. In the rise of the wave of eco-criticism, Cather novel exhibited eco feminist consciousness are getting more and more attention. This article aims to analyze Cather's "A Lost Lady," which reflects the ecological feminist ideology.

\section{AN ECO-FEMINIST OVERVIEW}

Eco-feminism is the product of the feminism combined with ecological conservation movement, but more is beyond both. 1974 French scholar Francois - Ao Boni first used the term "eco-feminism", so this school of thought appeared in the 1970s, marked an important progress in the 1990s. There have two such formulations on ecofeminism: feminist ecology and ecologic feminism. Ecofeminism trying to find a non-isolated culture from nature, and that an ecosystem

Scientists will certainly become a feminist. The purpose of eco-feminist criticism is to look for the absence of women and nature of the text. It queries the distorted and ignored others and marginalized things so as to collapse the male supremacy and supreme Fort Xin; at the same time it called for the whole community to pay attention to ecological issues and the female problems, make the world better and harmonious. Whether in the field of feminist studies, or in the field of ecological environmental protection studies, eco feminist are impressive school of doctrine.

Ecofeminism thought that human's oppression against women and nature is homologous nature in the ideological and cultural background and can not solve alone without addressing the other hand, its basic idea is that "the unreasonable rule among women, colored race, the children and the poor, there is an important connection."American Ecological feminist Warren seen women as the natural and physical Correspondance, the man is equal to human and mind, thus constitute a binary opposition. Conventional ideal thought that the body is not as noble as the mind and spirit, human nature is nobler than that, so the women are always inferior to men, according to the logic of domination, human's domination over nature is reasonable. From this perspective, she thinks that domination and oppression of nature and women in the ideological framework is homologous.

\section{III. "A LOST LADY" ECO FEMINIST INTERPRETATION}

\section{A. Women and natural oppressed status}

Famous ecological feminists Karin - Warren said: "oppression of nature and the oppression of women has important links, it is very necessary to understand this for the full understanding of the oppressions against nature and women suffered." Novel "a Lost Lady," the heroine Marion Kaiser • Forrest is shaped as a unique non-traditional female. 
Marion almost met all kinds of misfortunes women might suffer in her life. Adolescent's fiancé involves in a scandal and is murdered; Marion is helped by old Forrest and married him at the time to avoid the media. Old Forrest is aged and ill, since then she looks after her paralyzed husband carefully. But in his opinion, Marion is only part of his property or his property decorative embellishment, he is proud of "build a house, and friends can come and go, to find a wife like Mrs Forrest, so my friends think this place is lovely. "There is no difference between his pride on Marion and cattle and flowers he owned. He loves his wife to wear jewelry, which showed that "he can afford it and his wife can wear." Therefore, from his point of view, Marion is not an independent person, let alone the independent economy and she didn't need to know the management and operation of the property. When the supremacy of money and interests of business competition destroyed its former relaxed lifestyle, the shrewd and cunning Ivy - Peters controlled them in his hands, and Mr. Forrest have no ideal when Marion is humiliated by Ivey. Ivey's possession of Marion is not out of appreciation for Marion's talent, but was a part of the possession of old Forrest's property, which is a way to show his upstart status and the rights of male. Regardless of how Marion contempt for Ivey, but this time without the support of social and economic status, she can only endure humiliation in order to survive, just like the woodpecker whose eyes is carved out by cruel Ivy disoriented, desperately struggling to keep the ball rolling. In this patriarchal society, women are objects, playthings, the tools man show off others and all humble things, she is not, she should only be "human."

Meanwhile, the persecution of nature can be seen everywhere, and is considered a matter of course. Some ecofeminism theorists believe that male's enslavement to female began from enslavement of nature. The emergence of represents of the new pioneers Ivy $\bullet$ Peters

Makes Captain's earthly paradise lost its former peace and quiet, thus resulting in destroy of natural ecosystems. When children play merrily, boorish and arrogant Ivy unscrupulous but surreptitiously carrying shotguns, holding hunting bag there, the kids called him poison ivy, he does "disposed of" several dogs, and poisoned Judge's friendly long-haired dogs which shed tears, since that moment he must kill every dog he saw. Poison ivy wanton destruction of the natural environment is very miserable.

In front of the children, he brutally cut out a woodpecker's eyes, make it disoriented, rattling around, flying up and down, giving a panic and a sense of despair, from Ivy secretly poisoned several dogs in sweet town to breaking into the woods openly killed Woodpecker

Bird, duck, this series of events expose that human manhandles a non-human life, which is extreme swelling anthropocentrism performance. Ivey doesn't consider the fate of humans and other species as intertwined companions, but consider him as the masters and rulers of the nature.

More distressing is that crafty ivy doesn't recognize the close relation between natural ecology and spiritual ecology, and take full advantage of the economic crisis, when the Captain Forrest have difficulty in protecting his property, Ivy rent Mr Forrest's meadow, and drain off the swamp water into a cornfield. Ivey is mercenary, he change swamp to crops, for the economic interests, which not only destroy the well-maintained natural ecological, but also lead to the irreversible destruction of the ecological resources, and drainage problems along the Sweetwater River Valley in the rainy season. In fact, the marshes maintain the ecological balance of human needs, animal grazing and plant output, soil fertility. As a result, after the marshes are drained, "along Sweetwater River Valley the rain-soaked. River overflow the shore, all river are swell with water, Ivey • Peter's post-harvest stubble lying in the water. Forrest's House and City towns are separated by a puddle of water and two rushing creek. "Row marsh land reclamation is not only as a result of Ivey's disorder economic development, but the main thing is his lack of eco-consciousness. Ivey doesn't realize that human is only a part of nature and the expense of conquered nature is eventually buried their own. Therefore, the most urgent task for human is to develop the right ecological awareness, and gradually achieve mutual recognition between man and nature, to rebuild a harmonious relationship between man and nature, rather than opposite to it. People should live in harmony with nature, according to symbiosis.

Women as natural are on behalf of the original and passive. "Well-known Eco-feminist Warren makes it clear that the control of nature and women are in the same control system operation, this system is the patriarchal system. Overthrow the patriarchal system is the based work for women's movement and the environmental protection movement."

\section{B. Humans live in harmony with nature}

Ecofeminism believe that women have a great closeness with nature; women have a intimacy with nature, always hope to live in harmony with nature. So naturally, they have often been seen as a mother of nurturing all things. The outset of fiction shows the pastoral life of the Sweetwater town like a picturesque. Readers first see Captain Forrest's home, which is not only near a beautiful area of the triangle leaves woods, wide lawn, there are two rivers surrounded it. Unmodified river bend around again and again overflowing to half pasture, half marsh grass. There are mint, grass and even glitter willow in the both shores. "For the others, the prospective water will be drained off, instead yielding crops." But Captain Forrest thinks highly of this place, and feels it very beautiful. So, here is not only the earthly paradise of Mr. and Mrs Forrest, but the paradise for kids like Neill playing. Children often have a picnic and fishing here, they are standing on the imposing cliffs like animals yelling, go across the cobwebs which cover drops of condensing dew in the high weeds. They are" rushed toward silver-flicking swamp, ran in taupe cattail grass, jumped into the river with sediment playing water, chasing a water snake with striated sunning in the old willow, cut branches made slingshot. Drink cold spring water on all fours, the water overflow from the shore, flowing into Punta mustard grass. "Here is fairyland for a variety of flora and fauna," fresh and wild roses make the hillside bloom 
, streams eyes grass open with purple flowers, silver milkweed just flowering. Birds and butterflies are flying everywhere. "Flowers, water, butterflies and children constitute the ecological and beautiful picture of human went on well with nature. Captain's family and children enjoy the unlimited joy and fun of nature in this paradise.

\section{CONCLUSIONS}

After women break away from the male's oppression and discrimination, they can free to define themselves, to achieve self-realization, and at the same time they are also aware of everything in the universe, including human and non-human dignity, hope human to treat nature,

The task of ecofeminism is to combine eliminated gender oppression with eliminated oppression of nature to re-build a new feminist theory and practice, to eliminate the concept framework of binary system, and finally to achieve harmony and unity between person and person, between human and nature.

\section{References}

[1] Karen J. Warren.Feminism and Ecology [J] .Environmental Review, 1987: 3.

[2] Zhu Jiongqiang. Willa Cather selection - Set [M]. Beijing: Yanshan Press, 2004.

[3] Luo Ting. feminist literary criticism in the West and China[M]. Beijing: China Social Sciences Press, 2004.

[4] James Schroeter.Willa Cather and Her Critics [M] .Cornell University Press, 1967.

[5] Hh Zhihong. Western Ecological Criticism [M] Beijing: China Social Sciences Press, 2006

[6] Lu Shuyuan Ecological Literature Science [M] Xi'an: Shaanxi People's Publishing House, 2000.

[7] Wang Changrong. history of modern American fiction [M] Shanghai Shanghai Foreign Language Education Press, 1992.

[8] Zhang Yan ice feminist literary theory [M] Jinan: Shandong Education Press, 1998.

[9] Hu Zhi Hong, Jiufang. Research of eco-criticism "Ml Beijing: China Social Sciences Press, 2006

[10] Spender, Dale.Writing A NewWorId: Two Cen-turies of Australian WomenWriters [M] .London: Pandora1988.

[11] Hu Jinshan: "Racial Attitudes change white America's half of the 20th Century", "Xiamen University" (Philosophy and Social Sciences), 20042. 